Introduction

\title{
Introduction: SIPEX-2: A study of sea-ice physical, biogeochemical and ecosystem processes off East Antarctica during spring 2012
}

\section{Introduction}

This editorial introduces a suite of articles resulting from the second Sea Ice Physics and Ecosystems eXperiment (SIPEX-2) voyage by presenting some background information on the study area and Antarctic sea-ice conditions, and summarising the key findings from the project. Using the Australian icebreaker RV Aurora Australis, SIPEX-2 was conducted in the area between 115$125^{\circ} \mathrm{E}$ and $62-66^{\circ} \mathrm{S}$ off East Antarctica during September to November 2012. This region had been sampled during two previous experiments, i.e. ARISE in 2003 (Massom et al., 2006a) and SIPEX in 2007 (Worby et al., 2011a). The 2012 voyage combined traditional and newly developed sampling methods with satellite and other data to measure sea-ice physical properties and processes on large scales, which provided context for biogeochemical and ecological case studies. The specific goals of the SIPEX-2 project were to: (i) measure the spatial variability in sea-ice and snow-cover properties over small- to regional-length scales; (ii) improve understanding of sea-ice kinematic processes; and (iii) advance knowledge of the links between sea-ice physical characteristics, sea-ice biogeochemical cycling and ice-associated foodweb dynamics. Our field-based activities were designed to inform modelling approaches and to improve our capability to assess impacts of predicted changes in Antarctic sea ice on Southern Ocean biogeochemical cycles and ecosystem function.

\section{Background}

Antarctic sea ice is an integral part of the global cryosphere. It strongly influences, and is influenced by global climate, and is a key driver in Southern Ocean biogeochemical cycles and ecosystem processes (Arrigo, 2014; Massom and Stammerjohn, 2010; Thomas and Dieckmann, 2010). During maximum extent in September-October, it covers an area of approximately $19 \times 10^{6} \mathrm{~km}^{2}$ (or roughly $40 \%$ of the Southern Ocean surface), diminishing to $3-$ $4 \times 10^{6} \mathrm{~km}^{2}$ in summer (Parkinson and Cavalieri, 2012). The ice cover strongly affects Southern Ocean and global climate processes through the albedo-feedback mechanism, its insulating effect on the ocean's surface, and its role in driving global ocean circulation through the rejection of brine during ice formation. The sinking of rejected brine results in the production of Antarctic Bottom Water and drives thermohaline overturning circulation (Brandon et al., 2010; Jacobs, 2004; Rintoul, 1998). Moreover, the sea-ice melt back in spring-summer releases a large pulse of freshwater into the high-latitude Southern Ocean surface.

The strong seasonal sea-ice cycle and its variability is one of the fundamental factors affecting air-sea exchange of climate-active gases (including $\mathrm{CO}_{2}$ ) in the Southern Ocean, thereby also impacting ocean acidification (Delille et al., 2007; Fransson et al., 2013). In addition, sea ice affects Southern Ocean phytoplankton productivity in a number of complex ways, for example by limiting light availability but by serving both as a temporal storage for nutrients and organic matter and acting as a primer for phytoplankton blooms through meltwater-induced stratification at retreating ice edges in spring. Sea ice has also been shown to be a significant biogeochemically active reservoir for iron, a key limiting nutrient for primary production over large regions of the Southern Ocean (Lannuzel et al., 2015; Lannuzel et al., 2016; Schallenberg et al., 2016; Vancoppenolle et al., 2013).

Importantly, in terms of supporting the high-latitude marine ecosystems, sea ice serves as a substrate for ice algae that concentrate and grow in the surface, interior and basal layers of the ice (Arrigo et al., 2010; Meiners et al., 2012). A recent modelling study estimates that sea-ice algal production contributes approximately $12 \%$ to the total annual production in the Antarctic sea-ice zone and approximately $1 \%$ to total Southern Ocean primary production (Saenz and Arrigo, 2014). Although this represents a small fraction of total production, it is considered to be critically important for Southern Ocean ecosystem function, e.g. in supporting Antarctic krill (Euphausia superba).

Strong relationships have been shown between sea-ice extent (and duration) and the recruitment of Antarctic krill for some areas of the Southern Ocean, e.g. the West Antarctic Peninsula region and large parts of the south-west Atlantic (Atkinson et al., 2004). The mechanisms proposed for this relationship hinge on the reliance of krill (particularly krill larvae) on the algal communities that grow on the underside of the ice and the spatial refuge from predators provided by complex under- and intra-ice habitats (Flores et al., 2012; Massom et al., 2006b; Meyer, 2012; Virtue et al., 2016). Ice algae and associated sea-ice microbial communities represent a highly-enriched and spatially-confined food source for Antarctic krill during winter and early spring, when food in the water column is scarce (Meyer, 2012). However, exactly how larval krill can efficiently access this food source remains unknown (Daly 2004, Meyer et al., 2009) and whether this hypothesis can be applied to the East Antarctic sea-ice zone remains unclear (e.g. O'Brien et al., 2011). Krill is a key species in many Southern Ocean ecosystems as it provides a direct food-web link between primary producers and 
higher trophic levels, e.g. penguins, seals and whales. Coincident measurements of sea-ice parameters and krill under sea ice are therefore necessary to better understand the habitat utilisation of this keystone Antarctic species.

Given these factors, change in sea-ice coverage, processes and seasonality has extensive climatic, biogeochemical and ecological ramifications (Massom and Stammerjohn, 2010). While overall Antarctic sea-ice extent has increased slightly over recent decades, this comprises contrasting regional patterns of change and variability in both sea-ice extent and duration (Parkinson and Cavalieri, 2012; Reid et al., 2015; Stammerjohn et al., 2012) - including complex patterns across East Antarctica (Massom et al., 2013). Changing regional patterns of sea-ice coverage have been linked to changes in large-scale atmospheric circulation and the hydrological cycle as well as oceanic factors, although exact causes are currently unknown (Turner et al., 2015). Climate models predict that Antarctic sea ice will reduce significantly in both extent and volume by 2100 (Arzel et al. 2006; Smith et al. 2012), but with low confidence (Turner et al., 2015). Given the current lack of measurement capability and routine monitoring, changes in fundamental parameters such as sea-ice and snow-cover thickness (Maksym et al., 2012) and the coupled physical-chemical-biological processes in the high-latitude Southern Ocean remain poorly sampled and could be going unnoticed. Improved observational knowledge on the requirements of krill for sea-ice habitats with regard to sea-ice type, and the spatio-temporal use of these habitats in relation to their life history strategy, is necessary to understand the impacts of changing sea-ice conditions on Southern Ocean food webs and ecosystem function.

These critical knowledge gaps in our understanding of the coupled physics, biogeochemistry and ecology of the ice-covered Southern Ocean provided the motivation to conduct a multidisciplinary sea-ice voyage to the East Antarctic sea-ice zone, i.e. SIPEX-2. Specific aims of the voyage were to: (i) identify the spatial variability in sea-ice and snow-cover properties over small (m) to medium (100 km) length scales; (ii) improve understanding of sea-ice kinematic processes; and (iii) gain knowledge of the links between sea-ice physical characteristics, sea-ice biogeochemical cycling and ice-associated (sympagic) food-web dynamics in a data-poor sector of the Southern Ocean.

\section{Study area}

The SIPEX-2 study area and voyage operations are shown in Fig. 1. The general study area has been surveyed during previous Australian-led marine science voyages (e.g. BROKE-survey, Nicol et al. 2006), is visited annually by the Japanese Antarctic Research Expeditions ( 110 and $140^{\circ}$ E repeat transects, e.g. Aoki et al., 2005; Takahashi et al., 2015) and has also been sampled as part of dedicated sea-ice voyages, including the Australian-led ARISE (2003) and SIPEX (2007) voyages (Massom et al., 2006a; Worby et al., 2011a). The original SIPEX (2007) voyage in particular resulted in a wealth of data which provided scope for direct comparisons with the present, i.e. SIPEX-2 experiment (Jia et al., 2016; Steer et al., 2016; Toyota et al., 2016-a). Heil et al. (2016) provide a comparison of sea-ice conditions between the two years, and against the circum-Antarctic and longer-term picture. Climatological patterns of East Antarctic sea-ice coverage, drift and conditions are strongly influenced by the geographic setting (Massom et al., 2013; Post et al., 2014). The hydrographic conditions off East Antarctica are dominated by zonal circulation patterns comprising the eastward-flowing Antarctic Circumpolar Current to the north and the westward-flowing Antarctic Coastal Current to the south with some northward retro-flections (Heil and Allison, 1999; Massom et al., 2013; Schallenberg et al., 2016; Williams et al., 2011). The sea-ice cover in this area is strongly seasonal and occurs in a relatively narrow but very dynamic zone (Kohout et al. 2014; Kohout et al., (2016); Worby et al., 1998). The width of the East Antarctic sea-ice zone decreases from the west to the east, and in

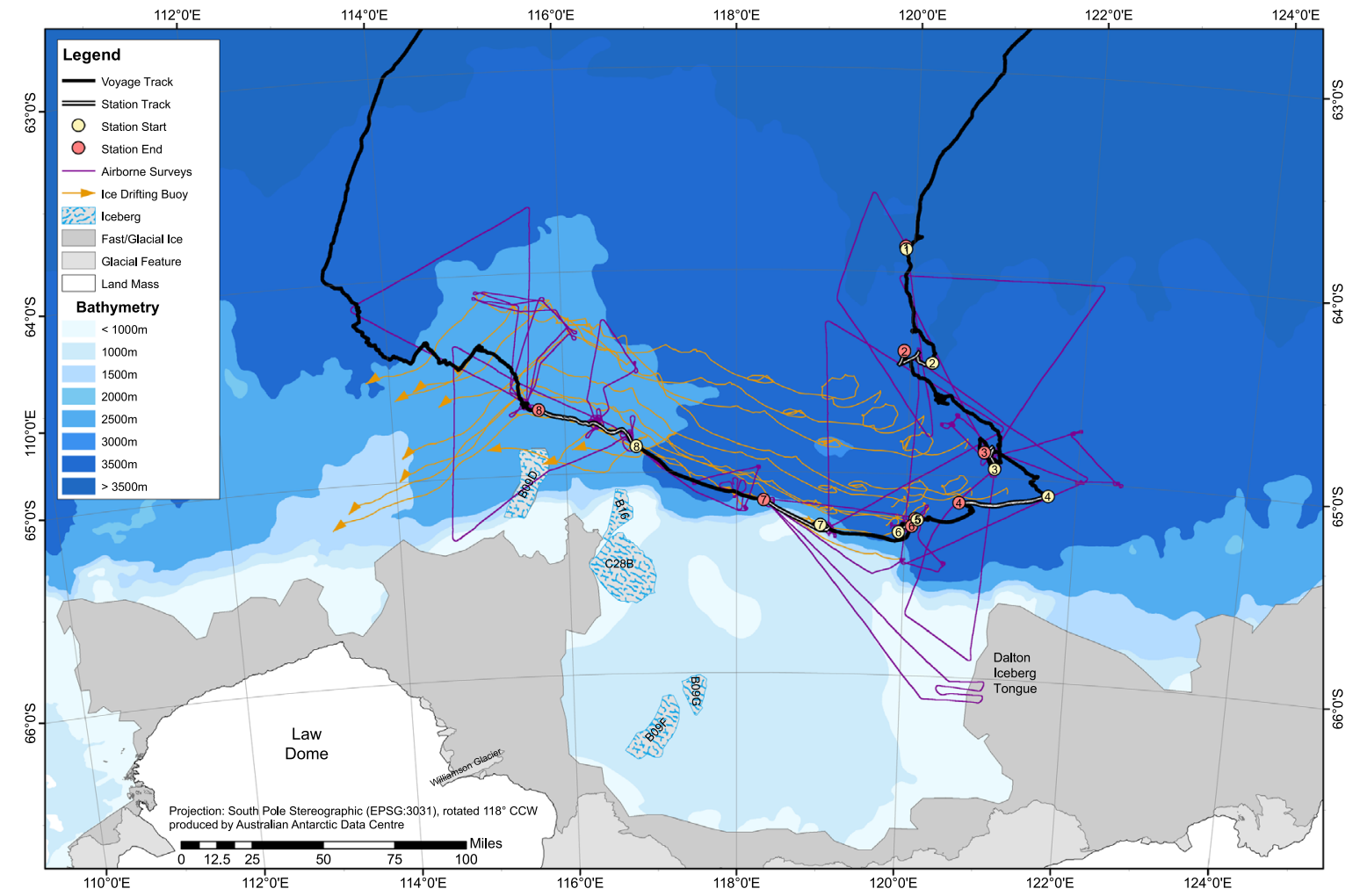

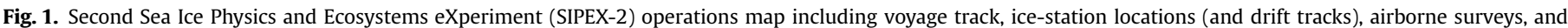
buoy tracks. 
the $100-120^{\circ} \mathrm{E}$ sector extends only a few degrees (equal to $300-$ $500 \mathrm{~km}$ ) from the coast during its maximum extent. This is particularly narrow compared to other sectors, e.g. the Weddell and Ross seas, where embayments extend to high latitudes and gyres generate sea-ice coverage that covers up to 20 degrees of latitude (equal to $>2000 \mathrm{~km}$ ) at maximum extent (Massom et al., 2013). The East Antarctic sea-ice zone is composed of several distinct but tightly-linked "icescape elements" e.g., the marginal ice zone (MIZ), the outer and inner pack-ice zones, and the coastal zone comprising land-fast (fast) ice and polynyas (Massom and Stammerjohn, 2010). Due to constant exposure to Southern Ocean storms and wave penetration, the MIZ can be extensive, with ice conditions (floe size, etc.) being strongly affected by wave-ice interaction (Kohout et al. 2014; Kohout et al., 2016; Toyota et al., 2016-b). This results in dynamic conditions and strong sea-ice thickening by rafting and ridging (Heil et al., 1998; Worby et al., 1998, 2011b) - to thicknesses in excess of $15 \mathrm{~m}$ in first-year ice as measured during SIPEX-2 by an autonomous underwater vehicle (AUV) (Williams et al., 2015). Regarding recent changes in areal coverage, a study by Massom et al. (2013) shows the trends in East Antarctic ice extent and duration since 1979 to be significantly more spatially complex compared to other sectors, e.g. the Amundsen/Bellingshausen and Ross seas (Massom et al., 2013; Stammerjohn et al., 2012).

Historically, the sea ice off East Antarctica has been considered to be relatively thin (Worby et al., 1998, 2008) (although large thicknesses have been estimated in coastal fast ice in places (Massom et al., 2010)) - with a relatively thin snow cover (Massom et al., 2001; Toyota et al., 2011). While snow insulates the sea-ice surface from the atmosphere to limit thermodynamic ice growth, high snow accumulation can result in surface suppression that induces surface flooding and subsequent ice thickening by snowice formation. This is thought to be an important though variable factor in East Antarctica (Maksym and Markus, 2008). Besides these physical implications, the effect of snow on sea-ice biogeochemical processes and algal growth, due to light attenuation and ice algal habitat formation in surface (flooded) layers (Fritsen et al., 1994; Saenz and Arrigo, 2012), is determined largely by its thickness and properties. Until recently, East Antarctic sea ice has been considered to be dominated by bottom ice algal communities (Grose and McMinn, 2003; McMinn et al., 2007; Meiners et al., 2011), which may provide a readily-accessible food source for krill - in particular larval and juvenile krill during winter and early spring (O'Brien et al., 2011; Meiners et al., 2012). The conditions encountered during the SIPEX-2 voyage were very different to those during previous studies in the area, and challenge the classical understanding of the coupled sea-ice physical and biological system and processes in East Antarctica (e.g. Roukaerts et al., 2016; Toyota et al., 2016-a; Williams et al., 2015).

\section{Results and discussion}

The SIPEX-2 voyage aboard RV Aurora Australis sailed from Hobart, Australia on 14 September 2012, and scientific operations in the sea-ice zone commenced on 23 September with the deployment of a number of waves-in-ice observation systems in the outer MIZ (at approximately $61.5^{\circ} \mathrm{S}$ and $121^{\circ} \mathrm{E}$ ). In total, in-situ measurements were acquired at 8 ice stations, ranging in duration from a few hours (due to ice-floe break-up) to multiple days, with on-ice work starting on 25 September (Fig. 1). The relatively small number of stations reflects the extreme nature of the sea-ice conditions encountered, i.e. heavily deformed thick first-year ice (Heil et al., 2016; Williams et al., 2015) with an unusually thick snow cover (Toyota et al., 2016-a), with the ship becoming entrapped and drifting with the ice for 10 days towards the end of the voyage. The last ice station (8) and the overall scientific programme were completed on 4 November 2012, and the Aurora Australis returned to Hobart on 16 November, 2012.

Away from the marginal ice zone, much of SIPEX-2 occupied a highly deformed ice pack with an uncharacteristically thick snow cover (Heil et al., 2016). In contrast to the northern bands of sea ice, the interior ice pack remained under pressure for most of the experiment. The presence of massive tabular icebergs has been disregarded as the primary source of the highly deformed pack of 2012. Instead, large-scale anomalies in atmospheric circulation, driven by a strongly positive Southern Annular Mode (SAM) in the summer preceding the field experiment, are believed to have given rise to anomalies in the ice drift, and consequently the extraordinary ice (and snow) conditions during SIPEX-2 (Heil et al., 2016).

The SIPEX-2 voyage activities encompassed the deployment of a variety of sea-ice drifting buoys including instruments to measure wave-decay from the open ocean, across the MIZ, and into the inner pack-ice zone (Kohout et al., 2015; Kohout et al., 2016, Toyota et al., 2016-b). These unique measurements showed that storm waves penetrate much deeper into the sea-ice zone than classical theory predicts and that waves can break up sea-ice floes far away from the ice edge (Kohout et al., 2014). Combined with airborne and satellitebased observations, these measurements also confirmed the role of waves in determining sea-ice floe-size distributions in the MIZ and the interior pack-ice zone (Toyota et al., 2016-b). Further analysis of the SIPEX-2 data has shown that waves have a strong amplifying effect on the retreat rates of the sea-ice edges during spring, thereby highlighting the potential key role of wave-ice interaction processes in driving Antarctic sea-ice extent (Kohout et al., 2014; Toyota et al., 2016-b).

The extraordinary nature of the sea-ice and snow conditions in spring 2012 and the SIPEX-2 region is discussed by Heil et al. (2016), Steer et al. (2016), and Toyota et al. (2016-a), with the mean snow thickness being three times higher than previous reports for the area. Combining in-situ measurements with atmospheric re-analysis data, Toyota et al. (2016-a) developed a regional snow mass-balance budget indicating that the high snow thickness encountered was most likely the result of reduced horizontal export (loss) of snow into areas of open water compared to previous years. Thus, snow thickness was likely not driven by precipitation, evaporation or snow-toice metamorphosis, but was rather a function of restricted snow redistribution, which in turn was a result of the high degree of seaice compaction and deformation encountered. The Toyota et al. (2016-a) study again highlights the importance of dynamic ice growth and deformation processes on the physical properties of East Antarctic sea ice. Steer et al. (2016), by combining data from the ARISE (2003), SIPEX (2007) and SIPEX-2 (2012) voyages to the East Antarctic sea-ice zone, show the non-linear relationship between snow thickness and ice deformation. Their study highlights current uncertainties in, and the need for improved in-situ validation of, emerging airborne and satellite methods that promise measurements of sea-ice freeboard and surface elevations (to estimate ice thickness) on larger scales.

By combining modelling with laboratory studies and field measurements, Jutras et al. (2016) and Lecomte and Toyota (2016) investigated the thermodynamic behaviour of surface slush-ice layers and the diurnal temperature development in snow on the ice, respectively. Their studies highlight the importance of snow wetness for the conductive heat flux across the snow-atmosphere interface and the importance of brine development during the freezing of slush-ice layers. Both processes can contribute significantly to sea-ice mass balance, and these new studies underline the need for more detailed parameterisation of snow-slush-ice surface processes in global scale sea-ice simulations. Both snowice formation and nutrient-replenishment processes depend on fluid flow through the porous brine microstructure of the sea ice. 
Measurements of the vertical fluid permeability were co-located with studies of the crystallographic, temperature and bulk-salinity profiles, demonstrating that the granular ice common in the Antarctic has a much higher percolation threshold than columnar ice (Golden et al., 1998; Golden et al., unpublished results).

Using SIPEX-2 data collected with an autonomous underwater vehicle (AUV) equipped with an upward-looking multi-beam sonar, Williams et al. (2015) provided the first detailed floe-scale icethickness measurements for East Antarctic sea ice. Their measurements show a high contribution of deformed ice, i.e. up to $70 \%$, compared to $10-20 \%$ deformation reported from historical shipbased observations (Worby et al., 2008). These results suggest that current estimates of Antarctic sea-ice thickness and volume based on existing observations may be too low. This again highlights the need for improved measurement capabilities to benchmark and monitor sea-ice properties, in particular ice and snow thickness on larger scales off East Antarctica and, more generally, in the Southern Ocean.

Biogeochemical studies conducted during SIPEX-2 focussed on the reservoirs and cycling of iron and sulphur compounds in the sea ice, i.e. dimethylsulfoniopropionate (DMSP), a methylated sulphur substrate produced by ice-associated algae and its degradation product dimethylsulphide (DMS), which is a climateactive gaseous compound. Lannuzel et al. (2016) showed that a higher proportion of the sea-ice associated particulate iron (PFe) is biogenic than previously thought and that the fertilisation potential of melting ice during sea-ice retreat may have been underestimated. The authors hypothesise that dissolved iron (DFe) may precipitate into PFe at distinct solubility thresholds, dependent on organic ligand concentrations within sea-ice brines. Measuring dissolved iron species in the water column, Schallenberg et al. (2016) showed that DFe concentrations in under-ice waters during SIPEX-2 were elevated compared to Southern Ocean background concentrations. DFe released by sea-ice brine rejection and drainage was identified as the dominant source of under-ice $\mathrm{DFe}$, but was insufficient to explain the overall under-ice DFe budget. Other likely sources contributing to DFe in under-ice waters were melting icebergs, shelf sediments as well as the particulate Fe fraction of the sea ice. Concentrations of reduced iron $(\mathrm{Fe}(\mathrm{II}))$ in under-ice waters were generally low, but slightly elevated at depth near the continent. Low Fe(II) concentrations in surface layers may have been the result of low light levels below the sea ice, combined with low primary productivity and low concentrations of electron donors, e.g. dissolved organic carbon.

Damm et al. (2016) developed a conceptual model of surface ice-algae DMSP production as a function of freeze-melt cycles combined with associated time-cycles of DMSP degradation and DMS production which explains a pulsed DMS release to the atmosphere. DMSP production is shown to be enhanced in sea ice with internal and surface algal communities, and is also shown to be influenced by seawater flooding of the sea-ice surface. Combined, these studies highlight the close links between biogeochemical sea-ice processes and the diurnal and seasonal dynamics of sea-ice physical properties. Physical and chemical processes occurring in sea ice during winter and early spring pre-condition biogeochemical and ecological processes later in the season, e.g. during times when temperatures and light levels increase and the sea ice becomes more coupled to the pelagic realm.

A number of SIPEX-2 studies investigated the distribution, primary production, (photo)-physiology and carbon allocation of ice algal communities. Ugalde et al. (2016) provide a detailed overview of the physical and biogeochemical characteristics of the SIPEX-2 ice stations. They also carried out ${ }^{14} \mathrm{C}$-uptake incubations to determine ice algal bottom-community production rates as well as their photosynthetic carbon allocation into intra- and extracellular carbon pools. Integrated ice algal biomass was generally low and dominated by internal and surface communities. Bottom ice algal communities, dominated by pennate diatom species, showed productivity rates in the range of previous studies but low overall production due to low biomass. This was most likely the result of strong light limitation due to the thick snow cover encountered at all stations. Focussing on the productivity of seaice internal algal communities and combining in-situ incubation techniques with a stable-isotopic tracer approach, Roukaerts et al. (2016) sampled ice algal communities over the entire thickness of the sea-ice cover, and report ice algal uptake rates for nitrate and ammonium. Their study identified two different production regimes in the sea ice. Sea-ice bottom communities showed preferential uptake of nitrate, i.e. new production, while sea-ice interior communities showed a high degree of ammonium uptake, i.e. regenerated primary production, with the latter likely fuelled by a detritus-based microbial food web.

Ice algae are considered to be an important early-season food source for pelagic herbivores, particularly larval and juvenile Antarctic krill (Meyer, 2012). Rafted and deformed sea ice, as encountered during SIPEX-2, may additionally serve pelagic organisms as a refuge from ocean currents and predation (Meyer, 2012). Comparing in-ice meiofauna and under-ice zooplankton communities sampled during both SIPEX and SIPEX-2, Wallis et al. (2016) provide a description of the influence of sea-ice biological properties, in particular the vertical distribution of ice algal biomass and sympagic meiofauna assemblages, on epi-pelagic zooplankton communities. Their data suggest that snow accumulation on deformed sea ice (Toyota et al., 2016-a) likely affected the vertical distribution of ice algae and sea-ice fauna with flow-on effects on epi-pelagic food webs. This underpins the emerging view that not only sea-ice quantity (e.g. sea-ice extent and duration) but also sea-ice quality (e.g. rate of deformation, snow cover, sea-ice thickness) and sea-ice biological properties (e.g. ice algal standing stocks and vertical ice algal biomass distribution) are important drivers of under-ice zooplankton community composition and pelagic processes (see Massom and Stammerjohn, 2010). The Wallis et al. (2016) findings also support previous observations of certain copepod species that use both bottom sea-ice layers and the under-ice realm as habitat, thereby exerting an especially strong influence on cryopelagic coupling and carbon flow.

These general observations on the importance of sea ice for pelagic species were underpinned by more detailed studies by Jia et al. (2016) and Virtue et al. (2016) focussing on zooplankton trophic interactions and larval krill dynamics, respectively. Jia et al. (2016) employed a stable-isotopic approach to identify dietary preferences and food-web links in under-ice zooplankton communities. Comparing SIPEX and SIPEX-2 samples, they showed that larval Antarctic krill (furcilia) exhibit dietary plasticity, e.g. herbivory when feeding on ice algal communities and greater heterotrophic food consumption when using both ice algal and pelagic food sources. This study suggests that warm and permeable ice, such as found during spring or pre-conditioned by deformation and high snow accumulation, is more likely to provide food for under-ice zooplankton than cold and un-deformed ice. This is counter-intuitive, as warm and permeable sea ice is often dominated by internal algal communities that may not be readily accessible for pelagic grazers. As highlighted by Virtue et al. (2016), food quality, e.g. content of poly-unsaturated fatty acids (PUFA), is also important for krill survival and conditioning - in addition to total ice algal biomass and its spatial distribution. Both studies further highlight the complexities in understanding the interactions between sea-ice and pelagic herbivores, and in predicting the impacts of changes in Antarctic sea-ice conditions on Southern Ocean ecosystem functions (see also Constable et al., 2014; Massom and Stammerjohn, 2010). 


\section{Concluding remarks}

Combined with previous investigations from the same region (in 2003 and 2007), the new SIPEX-2 results show that sea-ice properties exhibit high inter-annual variability in East Antarctica. Compared to previous spring-time voyages, however, sea-ice conditions were distinctly different during SIPEX-2 in 2012, i.e. more extreme thickness and deformation, a significantly thicker snow cover, and warm and permeable ice. This had flow-on effects on pack ice biogeochemical and ecological properties (e.g. the dominance of interior ice algal communities showing regenerated production) as well as under-ice food webs. Biological studies of pelagic processes identified ice algal communities as a food source for under-ice zooplankton and krill. In summary, the articles in this special issue present a suite of collaborative and cross-disciplinary research that yielded highly complementary results. Investigations conducted during SIPEX-2 underline the importance of repeat regional fieldstudies to understand Antarctic sea-ice physical processes and their effects on sea-ice biogeochemistry and ecosystem dynamics.

\section{Acknowledgements}

We are grateful for the support by captain Murray Doyle, and the officers and crew of the RSV Aurora Australis during the VMS 2012/ SIPEX-2 voyage. We like to express our special thanks to the voyage management team Andy Cianchi, Brett Free and Chris Gallagher for smooth and safe ice operations. We are also grateful to all those who helped obtain the measurements during SIPEX-2, particularly the AAD Science Technical Support team. This project was supported through (and contributes to) Australian Antarctic Science projects 4072, 4073, 4116 and 4140. SIPEX-2 was supported by the Australian Government's Cooperative Research Centres Programme through the Antarctic Climate and Ecosystems Cooperative Research Centre (ACE CRC). We are especially indebted to all reviewers for providing their valuable and constructive review comments for individual articles of this special issue.

\section{References}

Aoki, S., Rintoul, S.R., Ushio, S., Watanabe, S., Bindoff, N.L., 2005. Freshening of the Adélie land bottom water near $140^{\circ}$ E. Geophys. Res. Lett. 32 (L23601). http://dx doi.org/10.1029/2005GL024246.

Atkinson, A., Siegel, V., Pakhomov, E., Rothery, P., 2004. Long-term decline in krill stock and increase in salps within the Southern Ocean. Nature 432 (7013) $100-103$.

Arrigo, K. R., 2014. Sea ice ecosystems. Annu. Rev, Mar. Sci. 6, 439-467.

Arrigo, K.R., Mock, T., Lizotte, M.P., 2010. Primary producers in sea ice. In: Thomas, D.N., Dieckmann, G.S. (Eds.), Sea Ice, 2nd edition Wiley-Blackwell, Oxford, pp. 283-325.

Arzel, O., Fichefet, T., Goosse, H., 2006. Sea ice evolution over the 20th and 21st centuries as simulated by current AOGCMs. Ocean Model. 12 (3), 401-415.

Brandon, M.A., Cottier, F.R., Nilsen, F., 2010. Sea ice and oceanography. In: Thomas, D.N., Dieckmann, G.S. (Eds.), Sea Ice, 2nd edition Wiley-Blackwell, Oxford, pp. $79-111$

Constable, A.J., Melbourne-Thomas, J., Corney, S.P., Arrigo, K.R., Barbraud, C., Barnes D.K., Bindoff, N.L., Boyd, P.W., Brandt, A., Costa, D.P., Davidson, A.T., Ducklow, H. W., Emmerson, L., Fukuchi, M., Gutt, J., Hindell, M.A., Hofmann, E.E., Hosie, G.W., Iida, T., Jacob, S., Johnston, N.M., Kawaguchi, S., Kokubun, N., Koubbi, P., Lea, M.A., Makhado, A., Massom, R.A., Meiners, K.M., Meredith, M.P., Murphy, E.J. Nicol, S., Reid, K., Richerson, K., Riddle, M.J., Rintoul, S.R., Smith Jr, W.O., Southwell, C., Stark, J.S., Sumner, M., Swadling, K.M., Takahashi, K.T., Trathan, P. N., Welsford, D.C., Weimerskirch, H., Westwood, K.J., Wienecke, B.C., WolfGladrow, D., Wright, S.W. Xavier, J.C., Ziegler, P., 2014. Climate change and Southern Ocean ecosystems I: how changes in physical habitats directly affect marine biota. Glob. Change Biol. 20, 3004-3025.

Daly, K.L., 2004. Overwintering growth and development of larval Euphausia superba: an interannual comparison under varying environmental conditions west of the Antarctic Peninsula. Deep-Sea Res. II 51, 2139-2168.

Damm, E., Nomura, D., Martin, A., Dieckman, G.S., Meiners, K.M., 2016. DMSP and DMS cycling within Antarctic sea ice during the winter-spring transition. DeepSea Res. II 131, 150-159. http://dx.doi.org/10.1016/j.dsr2.2015.12.015.
Delille, B., Jourdain, B., Borges, A.V., Tison, J.-L., Delille, D., 2007. Biogas $\left(\mathrm{CO}_{2}, \mathrm{O}_{2}\right.$, dimethylsulfide) dynamics in spring Antarctic fast ice. Limnol. Ocean. 52 (4), 1367-1379.

Flores, H., van Franeker, J.A., Siegel, V., Haraldsson, M., Strass, V., Meesters, E.H., Bathmann, U., Wolff, W.J., 2012. The association of Antarctic krill Euphausia superba with the under-ice habitat. PloS one 7 (2), e31775.

Fransson, A., Chierici, M., Miller, L.A., Carnat, G., Shadwick, E., Thomas, H., Pineault, S., Papakyriakou, T.N., 2013. Impact of sea-ice processes on the carbonate system and ocean acidification at the ice-water interface of the Amundsen Gulf, Arctic Ocean. J. Geophys. Res. 118 (12), 7001-7023.

Fritsen, C.H., Lytle, V.I., Ackley, S.F., Sullivan, C.W., 1994. Autumn bloom of Antarctic pack-ice algae. Science 266 (5186), 782-784

Golden, K.M., Ackley, S.F., Lytle, V.I., 1998. The percolation phase transition in sea ice. Science 282 (5397), 2238-2241.

Grose, M., McMinn, A., 2003. Algal biomass in east Antarctic pack ice: how much is in the east? In: Huiskes, A.H.L., Gieskes, W.W.C., Rozema, J., Schorno, R.M.L., van der Vies, S.M., Wolff, W.J. (Eds.) Antarctic biology in a global context. Proceedings of the VIIIth SCAR International Biology Symposium, Backhuys Publishers, Leiden, pp. 21-25.

Heil, P. Allison, I., 1999. The pattern and variability of Antarctic sea ice drift in the Indian and Western Pacific sectors. J. Geophys. Res. 104 (C7), 15789-15802.

Heil, P., Lytle, V.I., Allison, I., 1998. Enhanced thermodynamic ice growth by sea-ice deformation. Ann. Glaciol. 27, 433-437.

Heil, P., Stammerjohn, S., Reid, P., Massom, R., Hutching, J., 2016. SIPEX 2012: Extreme sea-ice and atmospheric conditions off East Antarctica. Deep-Sea Res. II 131, 7-21. http://dx.doi.org/10.1016/j.dsr2.2016.06.015.

Jacobs, S.S., 2004. Bottom water production and its links with the thermohaline circulation. Antarct. Sci. 16 (04), 427-437.

Jia, Z., Swadling, K.M., Meiners, K.M., Kawaguchi, S., Virtue, P., 2016. The zooplankton food web under East Antarctic pack ice - a stable isotope study. DeepSea Res. II 131, 189-202. http://dx.doi.org/10.1016/j.dsr2.2015.10.010.

Jutras, M., Vancoppenolle, M., Lourenço, A., Vivier, F., Carnat, G., Madec, G., Rousset, C., Tison, J.L., 2016. Thermodynamics of slush and snow-ice formation in the Antarctic sea-ice zone. Deep-Sea Res. II 131, 75-83. http://dx.doi.org/10.1016/j. dsr2.2016.03.008.

Kohout, A.L., Penrose, B., Penrose, S., Williams, M.J., 2015. A device for measuring wave-induced motion of ice floes in the Antarctic marginal ice zone. Ann. Glaciol. 56 (69), 415-424.

Kohout, A.L., Williams, M.J.M., Dean, S.M., Meylan, M.H., 2014. Storm-induced seaice breakup and the implications for ice extent. Nature 509, 604-607.

Kohout, A.L., Williams, M.J.M., Toyota, T., Lieser, J., Hutchings, J., 2016. In situ observations of wave-induced sea ice breakup. Deep-Sea Res. II 131, 22-27. http://dx.doi.org/10.1016/j.dsr2.2015.06.010.

Lannuzel, D., Chever, F., van der Merwe, P.C., Janssens, J., Roukaerts, A., Cavagn, A.J., Townsend, A.T., Bowie, A.R., Meiners, K.M., 2016. Iron biogeochemistry in Antarctic pack ice during SIPEX-2. Deep-Sea Res. II 131, 111-122. http://dx.doi. org/10.1016/j.dsr2.2014.12.003.

Lannuzel, D., Grotti, M., Abelmoschi, M.L., van der Merwe, P., 2015. Organic ligands control the concentrations of dissolved iron in Antarctic sea ice. Mar. Chem. 174, 120-130.

Lecomte, O., Toyota, T., 2016. Influence of wet conditions on snow temperature diurnal variations: an East Antarctic sea-ice case study. Deep-Sea Res. II 131, 68-74. http://dx.doi.org/10.1016/j.dsr2.2015.12.011.

Maksym, T., Markus, T., 2008. Antarctic sea ice thickness and snow-to-ice conversion from atmospheric reanalysis and passive microwave snow depth. J. Geophys. Res., 113. http://dx.doi.org/10.1029/2006JC004085.

Maksym, T., Stammerjohn, S.E., Ackley, S., Massom, R., 2012. Antarctic sea ice - a polar opposite? Oceanography 25 (3), 140-151. http://dx.doi.org/10.5670/ oceanog.2012.88.

Massom, R.A., Stammerjohn, S.E., 2010. Antarctic sea ice change and variability physical and ecological implications. Polar Sci. 4 (2), 149-186.

Massom, R.A., Eicken, H., Hass, C., Jeffries, M.O., Drinkwater, M.R., Sturm, M., Worby, A.P., Wu, X., Lytle, V.I., Ushio, S., Morris, K., 2001. Snow on Antarctic sea ice. Rev. Geophys. 39 (3), 413-445.

Massom, R.A., Giles, A.B., Fricker, H.A., Warner, R.C., Legresy, B., Hyland, G., Young, N., Fraser, A.D., 2010. Examining the interaction between multi-year landfast sea ice and the Mertz Glacier Tongue, East Antarctica: another factor in ice sheet stability? J. Geophys. Res., 115. http://dx.doi.org/10.1029/2009JC006083.

Massom, R., Reid, P., Stammerjohn, S., Raymond, B., Fraser, A., Ushio, S., 2013. Change and variability in East Antarctic sea ice seasonality, 1979/80-2009/10. PloS one 8 (5), e64756.

Massom, R.A., Stammerjohn, S.E., Smith, R.C., Pook, M.J., Iannuzzi, R.A., Adams, N., Martinson, D.G., Vernet, M., Fraser, W.R., Quetin, L.B., Ross, R.M., Massom, Y. Krouse, H.R., 2006b. Extreme anomalous atmospheric circulation in the West Antarctic Peninsula region in austral spring and summer 2001/2, and its profound impact on sea ice and biota. J. Clim. 19, 3544-3571.

Massom, R.A., Worby, A., Lytle, V., Markus, T., Allison, I., Scambos, T., Enomoto, H. Tateyama, K., Haran, T., Comiso, J.C., Pfaffling, A., Tamura, T., Muto, A., Kanagaratnam, P., Giles, B., Young, N., Hyland, G., Key, E., 2006a. ARISE (Antarctic Remote Ice Sensing Experiment) in the East 2003: validation of satellite derived sea ice data products. Ann. Glaciol. 44, 288-296.

McMinn, A., Ryan, K.G., Ralph, P.J., Pankowski, A., 2007. Spring sea ice photosynthesis, primary production and biomass distribution in eastern Antarctica, 2002-2004. Mar. Biol. 151, 985-995.

Meiners, K.M., Norman, L., Granskog, M.A., Krell, A., Heil, P., Thomas, D.N., 2011. Physico-ecobiogeochemistry of East Antarctic pack ice during the winter-spring transition. Deep-Sea Res. II 58 (9), 1172-1181. 
Meiners, K.M., Vancoppenolle, M., Thanassekos, S., Dieckmann, G.S., Thomas, D.N., Tison, J.-L., Arrigo, K.R., Garrison, D.L., McMinn, A., Lannuzel, D., van der Merwe, P., Swadling, K.M., Smith Jr., W.O., Melnikov, I., Raymond, B., 2012. Chlorophyll $a$ in Antarctic sea ice from historical ice core data. Geophys. Res. Lett., 39. http: //dx.doi.org/10.1029/2012GL053478.

Meyer, B., 2012. The overwintering of Antarctic krill, Euphausia superba, from an ecophysiological perspective. Polar Biol. 35 (1), 15-37.

Meyer, B., Fuentes, V., Guerra, C., Schmidt, K., Atkinson, A., Spahic, S., Cisewski, B., Freier, U., Olariaga, A., Bathmann, U., 2009. Physiology, growth and development of larval krill Euphausia superba in autumn and winter in the Lazarev Sea, Antarctica. Limnol. Ocean. 54, 1595-1614.

Nicol, S., Pauly, T., Bindoff, N.L., Strutton, P.G., 2006. "BROKE”, a biological/oceanographic survey off the coast of East Antarctica $\left(80-150^{\circ} \mathrm{E}\right)$ carried out in January-March 1996. Deep-Sea Res. II 47 (12-13), 2281-2297.

O’Brien, C., Virtue, P., Kawaguchi, S., Nichols, P.D., 2011. Aspects of krill growth and condition during late winter-early spring off East Antarctica $\left(110-130^{\circ} \mathrm{E}\right)$. DeepSea Res. II 58 (9-10), 1211-1221.

Parkinson, C.L., Cavalieri, D.J., 2012. Antarctic sea ice variability and trends, 19792010. Cryosphere 6 (4), 871-880.

Post, A.L., Meijers, A.J.S., Fraser, A.D., Meiners, K.M., Ayers, J., Bindoff, N.L., Griffiths, H.J., van de Putte, A.P., O’Brien, P.E., Swadling, K.M., Raymond, B., 2014. Environmental settings. In: De Broyer, C., Koubbi, P., Griffiths, H.J., Raymond, B. Udekem d'Acoz, C., et al. (Eds.), Biogeographic Atlas of the Southern Ocean. Scientific Committee on Antarctic Research, Cambridge, pp. 46-64.

Reid, P., Stammerjohn, S., Massom, R., Scambos, T., Lieser, J., 2015. The record 2013 Southern Hemisphere sea-ice extent maximum. Ann. Glaciol. 56 (69), 99-106.

Rintoul, S.R., 1998. On the origin and influence of Adélie Land Bottom Water. Ocean, Ice, Atmos.: Interact. Antarct. Cont. Margin 8, 151-171.

Roukaerts, A., Cavagna, A.J., Fripiat, F., Lannuzel, D., Meiners, K.M., Dehairs, F., 2016. Sea-ice algal primary production and nitrogen uptake rates off East Antarctica. Deep-Sea Res. II 131, 140-149. http://dx.doi.org/10.1016/j.dsr2.2015.08.007.

Saenz, B.T., Arrigo, K.R., 2012. Simulation of a sea ice ecosystem using a hybrid model for slush layer desalination. J. Geophys. Res., 117. http://dx.doi.org/ 10.1029/2011JC007544.

Saenz, B.T., Arrigo, K.R., 2014. Annual primary production in Antarctic sea ice during 20052006 from a sea ice state estimate. J. Geophys. Res.: Ocean. 119 (6), 3645-3678.

Schallenberg, C., van der Merwe, P., Chever, F., Cullen, J.T., Lannuzel, D., Bowie, A.R., 2016. Dissolved iron and iron(II) distributions beneath the pack ice in the East Antarctic $\left(120^{\circ} \mathrm{E}\right)$ during the winter/spring transition. Deep-Sea Res. II 131, 96-110. http://dx.doi.org/10.1016/j.dsr2.2015.02.019.

Smith, K.L., Polvani, L.M., Marsh, D.R., 2012. Mitigation of 21st century Antarctic sea ice loss by stratospheric ozone recovery. Geophys. Res. Lett., 39. http://dx.doi. org/10.1029/2012GL053325.

Stammerjohn, S., Massom, R., Rind, D., Martinson, D., 2012. Regions of rapid sea ice change: an inter-hemispheric seasonal comparison. Geophys. Res. Lett., 39. http://dx.doi.org/10.1029/2012GL050874.

Steer, A., Heil, P., Watson, C., Massom, R.A., Lieser, J.L., Ozsoy-Cicek, B., 2016. Estimating small-scale snow depth and ice thickness from total freeboard for East Antarctic sea ice. Deep-Sea Res. II 131, 41-52. http://dx.doi.org/10.1016/j.dsr2.2016.04.025.

Takahashi, K.T., Iida, T. Ojima, M., Odate, T., 2015. Zooplankton sampling during the 55th Japanese Antarctic Research Expedition in austral summer 2013-2014. Jpn. Antarct. Res. Exped. Data Rep. 336 (49), 1-15.

Thomas, D.N., Dieckmann, G.S. (Eds.), 2010. Sea Ice, 2nd edition Wiley-Blackwell, Oxford.

Toyota, T., Massom, R., Tateyama, K., Tamura, T., Fraser, A., 2011. Properties of snow overlying the sea ice off East Antarctica in late winter, 2007. Deep-Sea Res. II 58 (9), 1137-1148.

Toyota, T., Kohout, A., Fraser, A.D., 2016-b. Formation processes of sea ice floe size distribution in the interior pack and its relationship to the marginal ice zone off East Antarctica. Deep-Sea Res. II 131, 28-40. http://dx.doi.org/10.1016/j. dsr2.2015.10.003.

Toyota, T., Massom, R., Nomura, O., Heil, P., Tamuru, T., Fraser, A.D., 2016-a. On the extraordinary snow on the sea ice off East Antarctica in late winter, 2012. DeepSea Res. II 131, 53-67. http://dx.doi.org/10.1016/j.dsr2.2016.02.003.

Turner, J., Hosking, J.S., Bracegirdle, T.J., Marshall, G.J., Phillips, T., 2015. Recent changes in Antarctic sea ice. Philos. Trans. R. Soc. A . http://dx.doi.org/10.1098/ rsta.2014.0163.

Ugalde, S.C., Westwood, K.J., van den Enden, R., McMinn, A., Meiners, K.M., 2016. Characteristics and primary productivity of East Antarctic pack ice during the winter-spring transition. Deep-Sea Res. II 131, 123-139. http://dx.doi.org/ 10.1016/j.dsr2.2015.12.013.

Vancoppenolle, M., Meiners, K.M., Michel, C., Bopp, L., Brabant, F., Carnat, G., Delille, B., Lannuzel, D., Madec, G., Moreau, S., Tison, J.-L., van der Merwe, P., 2013. Role of sea ice in global biogeochemical cycles: emerging views and challenges. Quat. Sci. Rev., 1-24. http://dx.doi.org/10.1016/j.quascirev.2013.04.011.

Virtue, P., Meyer, B., Freier, U., Nichols, P.D., Jia, Z., King, R., Virtue, J., Swadling, K.M., Meiners, K.M., Kawaguchi, S., 2016. Condition of larval (furcilia VI) and one year old juvenile Euphausia superba during the winter-spring transition in East Antarctica. Deep-Sea Res. II 131, 182-188. http://dx.doi.org/10.1016/j.dsr2.2016.12.001.

Wallis, J.R., Swadling, K.M., Everett, J.D., Suthers, I.M., Jones, H.J., Buchanan, P.J., Crawford, C.M., James, L.C., Johnson, R., Meiners, K.M., Virtue, P., 2016. Zooplankton abundance and biomass size spectra in the East Antarctic sea-ice zone during the winter-spring transition. Deep-Sea Res. II 131, 170-181. http://dx. doi.org/10.1016/j.dsr2.2015.10.002.
Williams, G., Maksym, T., Wilkinson, J., Kunz, C., Murphy, C., Kimball, P., Singh, H. 2015. Thick and deformed Antarctic sea ice mapped with autonomous underwater vehicles. Nat. Geosci. 8 (1), 61-67.

Williams, G.D., Meijers, A.J.S., Poole, A., Mathiot, P., Tamura, T., Klocker, A., 2011. Late winter oceanography off the Sabrina and BANZARE coast $\left(117-128^{\circ} \mathrm{E}\right)$, East Antarctica. Deep-Sea Res. II 58 (9-10), 1194-1210.

Worby, A.P., Ackley, S.F., Meiners, K.M., 2011a. Antarctic sea-ice zone research during the International Polar Year, 2007-2009. Deep-Sea Res. II 58 (9-10), 993-998.

Worby, A.P., Geiger, C.A., Paget, M.J., van Woert, M.L., Ackley, S.F., DeLiberty, T.L., 2008. Thickness distribution of Antarctic sea ice. J. Geophys. Res., 113. http://dx. doi.org/10.1029/2007JC004254.

Worby, A.P., Massom, R.A., Allison, I., Lytle, V.I., Heil, P., 1998. East Antarctic sea ice: a review of its structure, properties and drift. In: Jeffries, M.O. (Ed.), Antarctic Sea Ice: Physical Processes, Interactions and Variability, Antarctic Research Series 74. American Geophysical Union, Washington, pp. 41-67.

Worby, A.P., Steer, A. Lieser, J., Galin, N., Yi, D., Allison, I., Heil, P., Massom, R.A., Zwally, H. J., 2011b. Regional-scale sea ice and snow thickness distributions from in situ and satellite measurements over East Antarctic pack ice during the Sea Ice Physics and Ecosystem eXperiment (SIPEX). Deep-Sea Res. II 58 (9-10), 1125-1136.

Klaus M. Meiners

Australian Antarctic Division, Department of the Environment, 203 Channel Highway, Kingston, Tasmania 7050, Australia Antarctic Climate \& Ecosystems Cooperative Research Centre, University of Tasmania, Private Bag 80, Tasmania 7001, Australia

E-mail address: klaus.meiners@aad.gov.au

Ken M. Golden

University of Utah, Department of Mathematics, 155 S 1400 E RM 233, Salt Lake City, UT 84112-0090, USA

Petra Heil

Australian Antarctic Division, Department of the Environment, 203 Channel Highway, Kingston, Tasmania 7050, Australia Antarctic Climate \& Ecosystems Cooperative Research Centre, University of Tasmania, Private Bag 80, Tasmania 7001, Australia

Jan L. Lieser

Antarctic Climate \& Ecosystems Cooperative Research Centre, University of Tasmania, Private Bag 80, Tasmania 7001, Australia Institute for Marine and Antarctic Studies, University of Tasmania, Private Bag 129, Hobart 7001, Tasmania, Australia

Rob Massom

Australian Antarctic Division, Department of the Environment, 203 Channel Highway, Kingston, Tasmania 7050, Australia Antarctic Climate E Ecosystems Cooperative Research Centre, University of Tasmania, Private Bag 80, Tasmania 7001, Australia

Bettina Meyer

Alfred-Wegener-Institute Helmholtz Centre for Polar and Marine Research, Postfach 120161, 27515 Bremerhaven, Germany Institute for Chemistry and Biology of the Marine Environment, Carl von Ossietzky University of Oldenburg, Carl-von-Ossietzky-Straße 9-11, 26111 Oldenburg, Germany

Guy D. Williams

Antarctic Climate \& Ecosystems Cooperative Research Centre, University of Tasmania, Private Bag 80, Tasmania 7001, Australia Institute for Marine and Antarctic Studies, University of Tasmania, Private Bag 129, Hobart 7001, Tasmania, Australia 